\title{
A Study On The Legal Methodologies of International Law-Especially From The Aspect of International Labor Law
}

\author{
Xia Longyang \\ Ph.D Candidate of Faculty of International Law \\ China University of Political Science and Law
}

Beijing, China

\begin{abstract}
Keywords: International Law; International Labor Law; Methodology; Systematic Research; Positivism
\end{abstract}

\begin{abstract}
Methodology is one of important contents that the researchers need to master in the process of academic research. This article mainly discusses the methodology of international law, especially from the aspect of international labor law. It mainly contains two aspects: on the one hand, this article mainly discusses the research method of international law which is known by the author during the period of doctoral study, including the methodologies of systematic legal research, philosophic thinking, logic method, and the method of cross-over studies between international law and international relations, as well as the positivism research method of international law that pay attention to use data and charts as objective and neutral method to explain international rules. On the other hand, the article mainly states the author's research direction, that is research method related to international labor law. More importantly, as international labor law involves the basic human rights ,the researchers should have systematic and overall research method and vision.
\end{abstract}

\section{The Methodology of Systematic Research in International Law}

The Methodology of Systematic Research in International Law refers to view specific international law or international treaty in certain legal areas by the systematic opinion to establish the scientific research method in international law system. It will be helpful for our research and learning to take international law as a system.

The Connotation and Characteristics of the Research Method. System refers to a unified whole with specific functions which is made of several elements with mutual connection and interaction.[1] Methodology of systematic legal research is a new law school that introduced modern system science methods to legal research. System jurisprudence has the following distinctive features: the thinking that views things as a whole; analytical method of "SynthesizeAnalyze__Synthesize" for legal problems; Dynamic balance and interactive adaptation; etc. [2] The author's doctoral research subject is the Protection of Labor Rights and Interests in Transnational Mergers and Acquisitions, the research need to choose the research method with theoretical and practical significance because it involves international law, company law, labor law and many other laws. Therefore, I think that the methodologies of systematic legal research is a very suitable research method for the subject, it is also a research method repeatedly emphasized by Professor Xu Haoming in both his master and doctor classes in China University of Political Science and Law. It is very necessary for more scholars of International law to pay attention to it.Tthrough the collection and analysis of the materials for this subject, the author also thinks that it has important methodology significance to research international labor law from system law perspective.

Systematology is a theoretical system which is connected with researching the general pattern, principles and laws in all integrated systems or subsystems. It includes the concept of system, analysis of general system theory, system methodology and its application. As a complex whole, system is composed of certain elements and with certain structure. Its functions depend on its components and their correlation.

One of the important characteristics of system research method is to pay attention to integrity. Integrity refers to an organic whole rather than a simple combination of each part in system. 
Researchers could not only pay attention to one subsystem but ignore other subsystems. For example, the relevant provisions in the constitution level can not be ignored to research civil and commercial legal relations.

Another important characteristic of system research method is the internal correlation in system. Correlation refers to the mutual connection and interaction of the main parts in system. And the correlation of the main parts determines the overall status and properties of the legal system.

The Basis of Classification and Application in Higher-level Law and Lower-level Law. We need to differentiate the classification and application of higher-level law and lower-level law in the field of general laws for the purpose of mastering research method of international law from system law perspective.

1)The Classification of Higher-level Law and Lower-level law. According to the different legal ranks of validity, laws can be divided into three categories: higher-level law, lower-level law and same level law. Higher-level law has stronger validity, while lower-level law goes into effect according to its higher-level law. Same level law usually has the same validity. In general, compared with other department laws in a country, the constitution is the higher-level law. The reason is that other department laws are made on the basis of constitution. Therefore, civil law, penal law are lower-level law when they are compared with constitution.

2) The Validity of Higher-level law is Preferred than the Validity of Lower-level law. The judicial application of "higher-level law preferred than lower-level law" need a certain condition, it means that lower-level law is invalid when it is in conflict with higher-level law. If higher-level law is revised or abolished, but lower-level law still exists as the implemented provision, in "Circular of the Supreme People's Court on Printing and Issuing the Summary of the Symposium on Issues Concerning Applicable Legal Norms for the Trial of Administrative Cases" [3] :"If the law, administrative or local regulations is modified, but its implementated provision is not expressly abolished, People's Court shall distinguish the following situations in the application: the implementated provision shall not be applicable if it is in conflict with the modified law, administrative or local regulations; the implementated provision shall not be applicable if it loses the basis and can't be implementated alone because of the modification of law, administrative or local regulations; the implementated provision shall be applicable if it isn't in conflict with the modified law, administrative or local regulations." That means that the old lower-level law is invalid when it is in conflict with the new higher-level law.

3) Exception of The Rules__Priority Application of Lower-level law. If the lower-level law is made according to the authorization of higher-level law, or the lower-level law does not violate the provisions of higher-level law, the exception of "higher-level law preferred than lower-level law" will appear: priority application of lower-level law. The provisions of lower-level law and higher-level law in "The Law on Legislation of the People's Republic of China" mainly includes: (1) Central legislation is superior to the local legislation. (2)The legislation of the national legislative body is higher than administrative body even they are the same level. (3)The legal level of same type of legislations is determined in accordance with the legal status of their legislative body. (4)The validity rank of legal documents made by People's Congress is higher than its permanent organs which is Standing Committee.

The Methods of Systematic Research from International Law Perspective. The author thinks that we should focus on two aspects of applicable methods in systematic legal research when learning international law:

1) The overall grasp of various validity levels in international law

There are different legal levels between different international agreements and different legal norms: (1) "Marrakesh Agreement Establishing the World Trade Organization" has higher validity in WTO multilateral agreements; (2) The validity of international jus cogens is higher than other regulations which are not jus cogens in international legal system; (3)As Chinese researchers we should know that, when WTO agreement is converted into Chinese domestic law, the converted general law shall obey the Constitutional Law in China. The author can clearly understand and broadly master the international law throught the above summary. 
2) Observe the Interrelationship between Basic Principles of WTO from System Law Perspective

The basic principles of WTO law include: principle of MFN treatment, principle of national treatment, principle of different and preferential treatment in the developing countries. It should focus on four aspects to use the method of methodologies of systematic legal research to learn basic principles of WTO: (1) the lower-level law must conform to the higher ones, including WTO regulations.(2) When the lower-level law can be applied in the principles of diverse higher-level law, we must pay attention to the different legal value orientations in different legal principles in higher-level law. (3) Basic legal principles are the core of legal system, they determine which social relations can be selected as the important standard of the adjusted object in laws.(4) The basic legal principles contain the specific value orientation, they can be taken as the comprehensive or overall norms to "fill the law loopholes".

As a big developing country, China should learn the "legal principle of different and a preferential treatment specific for the developing countries" in international law. The principle mainly contains two aspects: one is different treatment, which refers to the longer transition promised for the developing countries to transform WTO laws and special provisions; another is preferential treatment, including the obligations of developed countries of Generalized System of Preference (GSP) for developing countries, as well as the mutual privileges among developing countries without applying principle of Most Favored Nation (MFN) treatment. Principle of "different and preferential treatment in the developing countries" more emphasizes the security for substantive fairness and equality, which is the realization of "substantial justice" and the basic principle that relates to "the survival and development rights in developing countries". Principles of " different and preferential treatment in the developing countries", " protection of human rights" and " protection of sovereignty" should be taken as the higher-level law of international law and have higher validity.

3) The Legal Hierarchy of WTO Law in American Legal System. There are three ranks of validity in American legal system: the constitution of the United States, federal law and state laws. WTO regulations are not directly applicable in the United States, "Uruguay Round Agreements Act" stipulates the validity of WTO regulations in American legal system. In September 1994, in order to execute the blanket agreements of Uruguay Round,the U.S. then-President Bill Clinton submit a budget "Uruguay Round Agreements Act" (URAA) to the United States Congress. In the meantime, the United States Congress approved the "URAA Statement of Administrative Action"

(URAA SAA), which was submitted accompanying with the URAA together. Sec102 Article of American "Uruguay Round Agreements Act" stipulates "Relationship of The Agreement to United States Law and State Law": "No provision of any of the Uruguary Round Agreement, nor the application of any such provision to any person or circumstance, that is inconsistent with any law of the United States shall have effect."[4]

It means that the application of the clauses in "Uruguay Round Agreements" are invalid for anybody or any circumstances if they are in conflict with the federal law of the United States. Sec102 article of American "Uruguay Round Agreements Act" also stipulates the provisions between WTO law and federal constitution or federal law. Sec102 (a) of "Uruguay Round Agreements Act" stipulate: "Nothing in this Act shall be constructed to amend or modify any law of the United States,including any law relating to (i) the protection of human, animal, or plant life or health, (ii ) the protection of the environment, or (iii ) worker safety."

It means that the clauses in "Uruguay Round Agreements" can't be used to modify or change any American law that relates to the following important social fields: the protection of the life and health of human, animal and plant; the laws related to the protection of environment and labor security. Therefore, it is a very important research method of international law to establish a comprehensive legal system and the important concept of system law for researchers of international law and national legislators.

The Research on International Labor Law from the Perspective of System Jurisprudence. 1) Integrate the International Labor Law into the Basic Human Rights System for Research 
First of all, it is of importance to integrate the international labor law into the human rights system in the process of studying the international labor law. Human rights refer to the rights enjoyed by individuals or groups as human beings. Despite the different understanding and practice of human rights, there is still consensus reached on the basis content of human rights.

a) Right to Life. It it the most fundamental and important human right. Other rights might be the castle in the air if the rights to humans' life cannot be guaranteed. It is an inhuman way to unlawfully deprive others of their life or impose threat, maltreatment or torture upon others. Individual rights will become unfounded if such situation is left neglected. For this reason, the criminal laws in all the countries usually sentence those encroaching on others' rights to life to heavy penalty. The safe and healthy workplace and working environment could ensure that the personal safety and health of workers or employees will be free from violation and the protection of the labors' rights to life and health serves as the basis of the safeguarding of their rights and interests.

b) Right to Freedom. Freedom is rated as the soul of human rights which including freedom of person, freedom of speech, freedom of communications and so on. The employees and workers have the freedom of choose one job or another as well as the freedom of continuing with this job or abandoning this job within the law. Meanwhile, they are also entitled to the freedom of managing their rest time besides their working time and choosing overtime work to obtain more salary. Therefore, the protection of labors and the rights to freedom of employees have also been made one of the most important content of safeguarding the labors' interests.

c) Property Rights. Property rights are the extension of rights to life and freedom. One has to be backed up by materials if he is to survive or choose his favorable lifestyle. Therefore, the exclusive possession of their labor income serves as the indispensable guarantee of their rights to life and freedom "It is a part of human dignities to work and live on the fruits of their labor and leave the left money to their children or their old age". [5] The property right seems to be a real right; however, it essentially refers to the domination of property by people, or the right of dominating their legitimate income. The work income of the labors and workers are the important source of their income. To safeguard their legitimate rights and interests, it is demanding to guarantee the timely and full funding of their incomes. In German legal system, there are four forms of collectively safeguarding the rights and interests of the employees, including the labor union, enterprise employee committee, safeguarding the rights and interesting of employees through board of supervisors and by the employees themselves. Among which, the former three forms refer to the solutions of "rule conflicts" aiming at improving the status quo and establishing the new rules; the last one is the solution of "dispute over rights", for example, the employees' joint indictment on the compensation payment by the employers.[6]

The author holds the opinion that establishing the new solutions for "conflict regularities" serves an important guarantee for the safeguarding of the employees' property rights, while the solution of "dispute over rights" is one of the specific manifestations of protecting the employee's property rights. It is demanding to give full play to the functions of union labor, enterprise employee committee and board of supervisors so as to safeguard the employees' property rights while attaching equal importance to the employees' action of appealing to the court in accordance with the Labor Law and initiative of safeguarding their property rights and interest. It is noteworthy and intereting that, in order to encourage labors to protect their own rights and interests, German labors can also have the right to institute legal proceedings in German Labour Court in the situation that without mediation program.[7] This is different with the regulations in Law on Labor Dispute Mediation and Arbitration of the People's Republic of China, Article 42 "Before rendering an award, an arbitral tribunal shall conduct mediation first.”

2) The Internal System Classification of Enterprise Labors’ Rights and Interests. The rights and interests of enterprise labors are divided into at least two levels, namely, the original rights and derived rights. The original rights refer to the guarantee of the survival rights and development rights that are intimately related to the labors' rights to life, which serves as the basis for the existence and development of the original rights and the derived rights. The derived rights are the 
rights granted and protected by the country and society. They are derived under the prerequisite of the existence of the original rights and added or deleted along with the temporal transition, variation of country and the changes of economic situation with the major rights and interests category including the social rights protected by unemployment insurance, retirement insurance and medical insurance.

The relationship between the original rights and derived rights. The original rights refer to the natural or inborn rights that come along with the birth of all the people and take the human essence or substantive characteristics as the protection content; therefore, the protection of which is unconditional and principal regardless of the country, economic conditions and time. There is a common consensus that it is the most fundamental, important, central and essential part in the protection of labor rights and interests. The derived labor rights and interests, together with the original rights, have constituted the core and indispensable part of the protection of labor rights and interests thanks to the worldwide popularization of Human Rights Act and consensus brought about by the development of human society despite the difference in the protection type, scope and depth under the conditions of various countries, time and economic conditions. Therefore, in the process of setting up the legal system pertaining to labors rights and interests, it is of prime importance to focus on the study of the core part of the original rights as the consensus and derived rights and expound on the difference caused by the various countries, time, economic conditions and political concepts in the non-core part of the labors' rights and interests protection law. This is the part that testifies to the flexibility and difference of the legal systems associated with labors' rights and interests. Therefore, it is necessary to set up the legal system of labors rights and interest that combine both principle and flexibility, consensus and difference.

\section{Focus on the Learning of Philosophy and Logic}

Philosophy is heralded as the mother of all sciences. The discussion of many issues should be risen to the philosophical level; at the meantime, the philosophical wisdom should guide people's life. Philosophy means "love wisdom" according to etymology. According to Shorter Logic by Hegel, philosophy, as a special movement of thinking, refers to the pursuit of absoluteness. "By taking the absoluteness as the object, philosophy is a special mode of thinking”.

Logic is a science related to the formation and rules of thinking. Logic has meanings of four levels and perspectives: Firstly, demonstrate the rules of the development of objective matters, for example, it does not conform to life logic. Secondly, demonstrate the regularity or rules of thinking, for example, it should conform to logic when speaking or writing articles. Thirdly, particular theory, viewpoint or statement, for example, "those who take control over seas, will dominate the world". Forth, science or action researching the form of thinking and its rules.[8]

At the meantime, it is also useful to know the three origins of logic, namely: one is the ancient Grecian logic represented by propositional logic of Aristotle and Stoic philosophy. Another is the logic in ancient China represented by Hui Shi, Gongsun Long, Mo Di and the scholars of younger age. Another is the Indian classical logic Yiming. Yiming refers to the forensics of India, it is the general term for the Buddhist logic. By widely reading the books of these experts, it is possible to lay a solid foundation to the study of international jurisprudence and the research in other realm of jurisprudence.

\section{Cross-over Research Method of International Law and International Relationship}

International relationship refers to a specific social relations which has been set up by human being and has transcended the traditional national boundaries. It mainly includes political relations, international regulations, economic interactions and so on.

In the tutorial class of methodology of jurisprudence for doctoral students, Professor Dr. Lin Canling told the students that when he pursuing further studies in Japan in his earlier age, he was once indignant at his Japanese teacher who said "China is a political power without political science". After returning to China, he found there was simply teaching and research room on 
politics rather than on political science. The difference in a single word may cause essential distinctions. As a scholar engrossed in International Law, Professor Dr. Lin said that the research into international relations is conducive to the study of international laws.

A review of the history of International Law shows that with respect to the cross-discipline of international jurisprudence and international relation theories, Zhou Gengsheng, Wang Tieya and Zhou Ziya, the late eminent international jurists, concentrated on the studies of politics and touched upon international politics and diplomacy in their younger years, a fact testifying to the relevance between international jurisprudence and international politics (theory of international relations). Introduction to International Law, the last book Mr. Wang Tieya bequeathed to the descendants, is a monograph related to the basic theory of international law that "follows the realistic view as the fundamental point in international law". For this reason, Mr. Wang called himself a " realist" and further explained that "this realism is not the one with 'power politics' as the content alleged by western scholars or with "policy orientation' as the guideline; the reality of my so-called realism is that of the international relations and that restricted by law".[9] It shows that Mr. Wang supported the method of studying International Law with the reality of international relations and took it as the feature of his own doctrine.[10]

In today's society, international relations are closely linked with international law, especially closely linked with the public international law. In the meantime, international relations are also affecting the development of private international law and international economic law. The research objects in international relations, are often the same research objects in international law, such as nations, international governmental organizations, non-governmental organizations, multinational corporations and so on. International organizations have formed an integral part of the international relations and international law. Many organizations for international relations are also the important organizations in the field of international law. One of the most famous international organizations is the United Nations. The United Nations defines itself as anorganization "To maintain international peace and security, and to that end: to take effective collective measures for the prevention and removal of threats to the peace, and for the suppression of acts of aggression or other breaches of the peace, and to bring about by peaceful means, and in conformity with the principles of justice and international law, adjustment or settlement of international disputes or situations which might lead to a breach of the peace". From the purposes of the United Nations we can see that it is involved with bothinternational relation and international law. There are also other many international organizations which have similar characteristics, such as European Court of Human Rights, Inter-American Court of Human Rights,International Criminal Court and so on.

\section{Research Method of Positivism of International Jurisprudence}

In the methodology of international jurisprudence, positivism stresses the application of objective and neutral research techniques with data and figures to explain the phenomenon of international law and find the issues related to international law from the wide and extensive international law practices.

The positive law school is a law school based on the positivist philosophy. Positivism is a western philosophical school that emphasizes sensory experience and rejects metaphysics. Originating from France and Britain in 1930s to 1940s, it was first proposed by Comte, the French philosopher and the earliest ancestor of sociology. The book series of The Course in Positive Philosoph gradually published since 1830 marked the formation of positivism. The positivism represented by Comte is called the old positivism and the logical positivism that gained enormous popularity called the neo-positivism.[11]

The legal positivism, also known as legal positivist theory and positive jurisprudence, is a contemporary school of jurisprudence and philosophy of right, which proposes the laws are manmade rules and there is no internal and necessary connection between laws and morality. In broad sense, the positivist jurisprudence stresses the relation between laws and society, the role of laws in society and the influence of society on laws. Philosophically, the bourgeois school of legal scholare 
could be classified into two categories: one is the positivist jurisprudence in broad sense and the other is the opposite natural jurisprudence.[12]

In terms of the research methodology of legal positivism and in accordance with the general proposition of positivism, the positivist research methodology could be generalized as a methodology of concluding the essential attributes and development rules of things by observing, testing and investigating the research object and obtaining objective materials. Against the backdrop of internationalization and informatization, the international event, diplomatic practice, case of international and domestic jurisdiction and arbitration, international treaty and domestic legislation are frequently reported by the digital media. Therefore, tracking and collection is much easier than that before the Internet era.

For the young people just starting with the studying of international law, the application of positivist methods necessitates techniques and costs; however, young people can start from lesser matters, for example, start with the judicial interpretation and in-depth analysis of case. It is a further step to resolve problems from the perspective of sociology of law. The current international practices, including the international treaty, domestic foreign-related legislation, international case and domestic case, offer abundant resources; the appropriate utilization will certainly yield useful outcomes. [13]

\section{Other Important Research Methodologies of International Jurisprudence}

Understanding and Skillful Usage of Legal Foreign Database in Foreign Language. 1) Lexis.com Database. Produced by American LEXIS-NEXIS Company, Lexis.com database is targeted at the legal professionals with 11439 data libraries, 31500 data sources and rich contents that even include all the industries. It is one of the most complete data banks especially in legal affairs. The legal research contents encompass cases of federal and state governments, cases of the supreme court in America, cases of the supreme court of appeal, cases of the local court: from 1789 till now; written judgment from state courts: including the written judgment of all levels in 50 states; more than 600 periodicals of legal reviews collection, such as Columbia Law Review, Harvard Law Review and Yale Law Journal; EU laws, including EC Treaties, EC Treaties in BDIEL, EU Case Law, European Court of Justice Cases, EU Legislation \& Regulations and EU Commentaries \& Treatises. The laws in other countries, including the decrees, articles of laws, cases, international conventions and the relevant legal materials in Britain, Germany, France, Ireland, Italy, Argentina, Australia, Brunei, Canada, Chinese Mainland and Hong Kong.

2) Westlaw Database. Westlaw Database, developed by Thomson Legal and Regulatory's, the largest legal publishing group in the world, in 1975, is an internet search tool provided for the international legal professionals and one of the largest legal databases. Case, laws and regulations, tables, treaties and commercial materials could be immediately acquired through Westlaw International, including library of American laws analysis, library of American federal substantive law, British criminal law, British corporate business, British intellectual property rights, British human rights, British proprietors and tenants, collection of Australian trade custom, collection of Australian financial service act, collection of Australian corporate laws, EU search materials base and the substantive laws in Hong Kong.

3) HeinOnline Database. HeinOnline database is the famous American legal periodicals full-text database with the legal research content including over 1000 full-texts of legal periodicals in America and other countries, legal precedents, treaties and agreements signed between America and other countries. The characteristic of this database is to record since the starting of publication. Among which, HeinOnline Foreign \& International Law Resources Database is the latest international law data launched by HeinOnline that collects full-texts (PDF format) of 675 volumes/ 500,000 pages of authoritative monumental works in the field of international law. The main contents of HeinOnline Foreign \& International Law Resources Database are divided into four parts: (1) International Yearbooks and Periodicals; (2) U.S. Law Digests; (3) International Tribunals/Judicial Decisions; (4) Other Significant Works related to Foreign and International Law. 
Like the HeinOnline full-text legal database, it is characterized by the basic format of images, comprehensive and overall content, long back-file and convenient and fast retrieval.[14]

Professional Proficiency in Legal English. The learning of and research on international law requires the study of the sources of international law. The sources of international law include two categories: one is the international law sources of strict legal significance, including international treaties and customs; the other is the international law sources with extensive historical significance, including the general legal principles and the auxiliary information determining the legal principles (refer in particular to judicial precedent, theory of international law and the resolution of important international organizations).

Provision 1 of Article 38 in the Statute of the International Court of Justice is: "The Court, whose function is to decide in accordance with international law such disputes as are submitted to it, shall apply: a. international conventions, whether general or particular, establishing rules expressly recognized by the contesting states; b. international custom, as evidence of a general practice accepted as law; c. the general principles of law recognized by civilized nations; d. subject to the provisions of Article 59, judicial decisions and the teachings of the most highly qualified publicists of the various nations, as subsidiary means for the determination of rules of law." This Statute of the International Court of Justice lists all the formal sources of international law in broad sense, meaning that the court should judge the various disputes in accordance with the international law.

As shown not only in the composition of international law sources, such as the international treaties and customs, but also in the theory of international law, the resolution of important international organizations and the Statue of the International Court of Justice require the excellent proficiency in foreign languages. Besides English, the author also agrees with the importance of French because many of the documents of international laws are published in French. At the meantime, German, Spanish and Portuguese are also minority languages of great importance. The author holds the idea that the outstanding foreign language research ability serves as an edged tool for international law learning. A good mastery of the minority language opens a new window for the research into international law.

\section{Conclusions of the Study}

Above all, as a doctoral student engrossed in international law, the author thinks that each person has a research methodology of international law that is suitable for themselves. What benefits the author most includes: research method of system jurisprudence; cross-over research method attaching importance to the study of philosophy and logic as well as international law and international relationship and the positivism research method of international law explaining the international legal phenomenon with objective and neutral research method of positivism combing data and graphs. What's more, in the process of the author's leaning of international jurisprudence, skillful adoplication of legal database in foreign languages, such as Lexis and HeinOnline as well as the enhancement of foreign language proficiency are also important research methods. The author believes that with the constant application and practice of the research methods explained in this paper, greater progress will be achieved in the research into international jurisprudence.

\section{References}

[1] Wanling. The Legal Protection for Financial Consumers in System Law Horizon - Use Structural Elements to Analyze Chinese And American System. Law Forum (12) 2011. Page 113.

[2] C.Z. Shi. Analysis of Law Failure in System Jurisprudence. China University of Political Science and Law, Oct. 2007.

[3] Issuing authority: Supreme People's Court of PRC. Document Number: 96. Date issued: May,18,2004. Level of Authority: Documents of Judicial Interpretation Nature. Area of law: administrative litigation. http://www.lawinfochina.com/display.aspx?lib=law\&id=10014 
[4] See: "United States Law to Prevail in Conflict"in SEC102 of Uruguay Round Agreements Act.

[5] http://zh.wikipedia.org/wiki/\%E4\%BA\%BA\%E6\%9D\%83\#cite_ref-16, the latest access time: April 20, 2015.

[6] Wolfgang Däubler.The Protection of German Employees' Rights and Interests. Beijing: China Workers Publishing House, 2009,Page 4.

[7] (Germany) Wolfgang Däubler. The Protection of German Employees' Rights and Interests. Beijing: China Workers Publishing House, 2009, Page 5.

[8] http://baike.baidu.com/subview/1838/5033469.htm\#refIndex_1_5033469, the latest access time: April 20, 2015.

[9] T.Y. Wang. Introduction to International Law: Preface [M] Beijing: Peking University Press, 1998.

[10] C.L. Xu. Establishment of International Law and Jurisprudence---The Cross-Discipline of International Jurisprudence and International Relations Theory, . Study of Comparative Law, 2009, (4): Page 25.

[11] http://baike.baidu.com/view/51528.htm?fr=aladdin, the latest access time: April 20, 2015.

[12]http://baike.baidu.com/link?url=Oae_igg5vbr7NLtMIKb9EgbUa7B9F-6WX5-

ZPP4f6sUd4cgMduMqHyDZbAIpurdo, the latest access time: April 20, 2015.

[13] Song Lianbin. Focus on Empirical Research in International Law Study. Huaqiao University ( Philosophy and Social Science Edition) .2010, (1): Page 53.

[14]

http://web.cupl.edu.cn/html/library/library_633/20111229102206589529032/201112291022065895 29032.html, the latest access time: April 20, 2015. 